\title{
Considerations for the Design of a Perinatal Mindfulness Intervention for Adolescents Based on a Systematic Review of the Literature
}

\author{
Review \\ Kymberly L. Kvasnak ${ }^{1}$, Ginny Brunton ${ }^{1}$, Manon Lemonde ${ }^{1}$, Barbara Chyzzy², Jennifer Abbass-Dick ${ }^{1}$ \\ ${ }^{1}$ Faculty of Health Sciences, Ontario Tech University, Oshawa, Ontario, Canada; ${ }^{2}$ Daphne Cockwell School of Nursing, \\ Ryerson University, Toronto, Ontario, Canada \\ Corresponding author: B. Chyzzy (barbara.chyzzy@ryerson.ca)
}

\section{ABSTRACT}

Objectives: This systematic review of the literature was conducted to determine the best way to design mindfulness interventions for perinatal adolescent mothers to support mental health during the transition to parenthood and beyond. Perinatal adolescents face unique challenges compared to adults due to their developmental stage and difficulties accessing social determinants of health. Mindfulness educational interventions may be an ideal addition to perinatal supports to foster resilience and teach skills to reduce stress, anxiety, and depression. Methods: A search strategy was developed to identify articles from 6 electronic databases including Psyclnfo, ProQuest, PubMed, Cochrane Library, Ovid, and CINAHL. Qualitative analysis was done to identify mindfulness interventions which significantly decrease anxiety, depression, or stress and to determine the components and designs of these interventions. Participants' satisfaction with the interventions were analyzed, when available. Best practices for designing interventions for adolescents were used to recommend adaptations to the mindfulness interventions to tailor them to the perinatal adolescent population. Results: Of the 561 studies retrieved from the search, 16 met the inclusion criteria. All included studies found at last one significant decrease in mental health outcomes (stress 9 of 13, anxiety 9 of 9; depression 9 of 14). The majority of the interventions began in the perinatal period, were delivered face-to-face, included homework, multiple sessions and by a trained professional. Conclusion: Mindfulness interventions are feasible, acceptable and effective in adult perinatal populations. Components and design of these interventions could be adapted for perinatal adolescents to increase resilience to cope with unique parenthood challenges.

\section{KEYWORDS}

Adolescent; Childbirth Education, Mindfulness, Perinatal, Systematic Review

\section{INTRODUCTION}

Perinatal adolescents are faced with a unique set of challenges during pregnancy, childbirth and parenting and are at an increased risk for mental health challenges (Corcoran, 2016; Kingston, Heaman, Fell, \& Chalmers, 2012; Siegel \& Brandon, 2014). Approximately 44,000 women ages $15-24$ years gave birth in Canada in 2019 (Statistics Canada, 2021) with $30 \%$ of mothers under the age of 25 reporting feelings of depression and anxiety in the first year postpartum (Statistics Canada, 2019). Pregnancy and childbirth in vulnerable populations such as adolescents can negatively impact the physiological development of both mother and child postpartum (Anderson \& McCarley, 2013; Anderson \& McGuiness, 2008; Kingston et al., 2012; Siegel \& Brandon, 2014; Zaers, Waschke, \& Ehlert, 2008). The children of mothers who struggle with mental health during pregnancy and postpartum can experience a diverse range of negative health outcomes, including developmental, behavioral, and cognitive difficulties, in addition to being at risk of developing mental health problems themselves (Budden et al., 2016). Research suggests 
that perinatal adolescents experience poor mental health (Anderson \& McGuiness, 2008; Siegel \& Brandon, 2014; Zaers et al., 2008), Post-Traumatic Stress Disorder (PTSD) (Anderson \& McGuiness, 2008; Anderson \& McCarley, 2013; Zaers et al., 2008), and maternal-fetal attachment issues (Mercer, 1995; Sauls, 2004; Scott, Klaus, \& Klaus, 1999). Modifiable factors which are amenable to interventions should be explored to address these clinical issues. One such intervention is perinatal mindfulness education, as this has been designed and piloted in adult populations with preliminary evidence suggesting this intervention can support mental health (Dhillon, Sparks, \& Duarte, 2017; Hall, Beattie, Lau, East, \& Biro, 2016; Lever Taylor, Cavanagh, \& Strauss, 2016; Matvienko-Sikar, Lee, Murphy, \& Murphy, 2016; Shi \& MacBeth, 2017). Nevertheless, it is not known how to best deliver these interventions to the adolescent perinatal population, to meet their developmental learning needs.

\section{PURPOSE}

The purpose of this systematic review is to determine mindfulness intervention designs that have been delivered to perinatal women and found to be effective in decreasing stress, anxiety and depression and make recommendations as to how these interventions can best be tailored for perinatal adolescents to assist them in building resilience and improve mental health outcomes (stress, anxiety, and depression).

\section{CONCEPTUAL DEFINITION}

\section{Mindfulness}

Mindfulness refers to an awareness of our thoughts, feelings, bodily sensations, and surrounding environment (Kabat-Zinn, 2003). This core operational definition is utilized in various mindfulness-based programs: Mindfulness-Based Stress Reduction (MBSR), Mindfulness-Based Cognitive Therapy (MBCT) are the two most studied and employed mindfulness-based interventions (Gu, Strauss, Bond, \& Cavanagh, 2015).

Mindfulness training in adolescents has been found to promote positive outcomes such as increased self-esteem, resilience and emotional regulation, and decreased stress, anxiety, and depression (Broderick \& Frank, 2014; Tan \& Martin,
2012; Volanen et al., 2016; Zack, Saekow, Kelly, \& Radke, 2014). In the adult perinatal population, mindfulness training has been identified as a skill which significantly decreased stress, depression and anxiety, and significantly increased mindfulness and positive affect, one's ability to manage pain, empathy, self-compassion, relaxation, and body awareness (Byrne, Hauck, Fisher, Bayes, \& Schutze, 2013; Goodman et al., 2014; Woolhouse, Mercuri, Judd, \& Brown, 2014).

Mindfulness is a practice that is becoming increasingly more common for the reduction of stress and the promotion of health. Mindfulness training has the capacity to yield beneficial effects on physical and mental health, and cognitive performance, while promoting personal growth and development by teaching one to nurture and protect the brain (Tang, Holzel, \& Posner, 2015). Offering transferable skills to many areas of life, mindfulness can be of assistance when life stressors are encountered. Mindfulness training during the perinatal period for adolescent mothers may be an ideal skill to build resilience to assist young mothers through labour and childbirth, in addition to building the skills and capacity to withstand the stresses experienced in parenthood and with obtaining the social determinants of health (SDOH).

\section{Mindfulness in Perinatal Populations}

There is an emerging trend in using mindfulnessbased interventions with adult perinatal women to improve mental health. The results of five published systematic reviews suggest that mindfulness interventions delivered to perinatal adult women have been found to be effective in decreasing depression, anxiety, and stress and the qualitative data consistently suggests that participants view mindfulness interventions positively; perinatal women enjoy these interventions. (Dhillon et al., 2017; Hall et al., 2016; Lever Taylor et al., 2016; Matvienko-Sikar et al., 2016; Shi \& McBeth, 2017). Nevertheless, findings should be considered with caution as bias was present in all five reviews due to study design; future studies should use rigorous methods to examine intervention effects.

\section{Mindfulness for Adolescents}

Designing a perinatal mindfulness intervention targeting adolescents requires an understanding of 
the manner in which they prefer to receive information. Three systematic reviews about mindfulness interventions with the adolescent were reviewed (Cheang, Gillions, \& Sparkes, 2019; Kostova, Levin, Lorberg, \& Ziedonis, 2019; McKeering \& Hwang, 2019). McKeering and Hwang (2019) examined mindfulness interventions delivered to the adolescent population in schools. Eleven of the 13 studies in their review found positive improvements in mental health. Kostova et al. (2019) reviewed mindfulness interventions, which included adolescents experiencing mental health conditions and found that interventions were feasible and well accepted, however clinical outcomes needed further investigation. Lastly, Cheang et al. (2019) explored the impact of mindfulness on empathy and compassion in adolescents and found some evidence to suggest that mindfulness increases self-compassion amongst this population. Findings also indicate that mindfulness interventions are being designed and evaluated with diverse groups of adolescents.

\section{Designing Interventions for Adolescents}

Although there are emerging curricula for mindfulness interventions for children, at this time, no such protocol has been developed for adolescents (Kostova et al., 2019). These reviews provide some considerations regarding the delivery of mindfulness interventions to adolescents. McKeering and Hwang (2019) noted the importance of having a facilitator lead the mindfulness session, as some students found it boring and difficult to practice due to invasive and recurrent thoughts and their minds wandering. Participants suggested that the mindfulness facilitator's skill set and knowledge be based in both mindfulness and the target population (adolescents). The facilitator's practice was more widely accepted when an explanation that a wandering mind and similar challenges are a normal part of mindfulness practice; this may help in preventing adolescents from thinking they are practicing mindfulness incorrectly, and in turn becoming disengaged (McKeering \& Hwang, 2019). This is important, as adolescent's engagement is critical to learning (Registered Nurses' Association of Ontario (RNAO), 2010). Kostova et al. (2019) suggestions include: (1) interventions should be adapted to the specific challenges of the teens, discuss situations that teens encounter in their daily life, making it more relatable and engaging, (2) it should be participatory and interactive, include role play, and experiential learning through mindful exercises that bring awareness to the senses, (3) shortened sitting sessions that are increased gradually as tolerated, as some adolescents may have short attention spans, and the longer sittings common in adult populations can be challenging, (4), sessions no longer than 90 minutes to accommodate short attention spans, (5) discussing participant goals before the session, as this may improve engagement and motivation, and (6) parental training in addition to adolescent training may be effective. Cheang et al. (2019) notes that it would be suitable to examine mindfulness-based interventions with adolescents, as they are often under-represented. Doing so may assist in defining the time in development in which mindfulness interventions may be most helpful in meeting a child's needs or cognitive ability (Cheang et al., 2019). Congruent with McKeering and Hwang (2019), Cheang et al. (2019) suggests that it may be feasible for mindfulness-based interventions to be conducted within schools, without the need to hire specialist staff, making this kind of intervention more accessible to school-aged children on a larger scale (Cheang et al., 2019).

\section{METHODS}

A search strategy was developed to systematically identify published, peer reviewed articles from 6 electronic databases including Psyclnfo, ProQuest, PubMed, Cochrane Library, Ovid, and CINAHL. The initial search took place in December 2018; an updated search was conducted in July 2019. Searches were conducted using keywords in various combinations (Table 1). Searches were organized and recorded to ensure no duplication of results occurred. No limits on the search dates were added. Additional articles were selected manually from Google Scholar and reference lists of articles reviewed and included if they fit the inclusion criteria. Consultation with a librarian and academic faculty with expertise in this area took place to ensure the search strategy was comprehensive.

Initial abstract screening was conducted to deem potentially relevant articles and the full text was then screened using the following criteria. For studies to be included in the review they had to meet the inclusion criteria: (1) published in English, (2) published in a peer-reviewed journal, (3) study sample included perinatal women, (4) the intervention focused on mindfulness training, (5) the published manuscript 
provided data on at least one of the primary outcomes (stress, anxiety, and depression), and (6) research designs were randomized controlled trials or quasi-experimental.

Exclusion criteria consisted of: (1) a review of a Dialectical Behaviour Therapy (DBT) or Acceptance and Commitment Therapy (ACT) interventions, the use of mindfulness with other modalities such as biofeedback, alternative cognitive behavioural therapy, or yoga as a principal component, to reduce extraneous variable impact on outcomes of interest, (2) original data was not presented, and (3) articles solely of qualitative design.

\section{Data Extraction and Analysis Plan}

Data extracted included components consistent with the standardized Cochrane Pregnancy and Childbirth Group Data Extraction (PCG) (Cochrane Editorial Resource Committee, N.D.) and include: (1) program, (2) format, (3) weeks/hours, (4) setting, (5) gestation, (6) number of contacts, (7) provider, and (8) country study was conducted.

The analysis plan consisted of determining: (1) the statistically significant findings related to stress, anxiety and depression, (2) characteristics of effective intervention components and design, and (3) if effective characteristics align with suggested practices for adolescent mindfulness interventions.

A narrative analysis was conducted to analyze estimates of mindfulness intervention effects; this included organizing study findings into a comprehensive textual narrative, with descriptions of differences in characteristics of the studies explored (Campbell, Katikireddi, Sowden, McKenzie, \& Thomson, 2018). Guidelines set out by the UK Economic and Social Research Council on the conduct of narrative synthesis were used (Campbell et al., 2018). Study details were collected to determine study population characteristics. For the perinatal adult population, the following study details were extracted (1) target sample, if the participants were healthy or diagnosed with mental health concerns, (2) sample size, (3) setting, (4) country study was conducted, and (5) the stage of the perinatal period.

A comparison framework was used to identify if the research evidence surrounding perinatal mindfulness interventions correlated with suggested practices for adolescent mindfulness education recommendations; this comparative method of synthesis has been used in Evidence for Policy and Practice Information and Co-ordinating Centre reviews (O'Mara-Eves et al., 2013). Comparisons of the following intervention elements were included: (1) type (e.g., perinatal education and psychotherapy), (2) format (e.g., face- to-face instruction, individual or group, homework, online component [video, website, or application, etc.]), (3) length of intervention and number of sessions, (4) number of contacts (single or multiple), and (5) provider (e.g., healthcare professional, childbirth educator, lay, or peer). Characteristics of interventions were collected in accordance with the elements indicated on the Template for Intervention Description and Replication (TIDieR) checklist (Hoffmann et al., 2014).

Seven suggested practices for an adolescent mindfulness intervention were selected based on the recommendations from three systematic reviews (Cheang et al., 2019; Kostova et al., 2019; McKeering \& Hwang, 2019). These include facilitator capacity, delivery method, flexibility/adaptability, interactive and engaging curriculum, session length, reflection/discussion, and support training (parent/caregiver or partner of adolescent) design features which will be compared to effective perinatal mindfulness intervention components found in the included studies.

Effectiveness of mindfulness interventions in decreasing stress, anxiety, and depression were determined. For the studies found to be effective in improving these outcomes, the intervention components were analyzed and compared to recommendations for providing adolescent mindfulness education. To assess for differences in outcome risk of bias rating a sensitivity analysis was conducted, where studies were assessed visually (Higgins \& Green, 2011). Based on this analysis, recommendations were made for adaptation of a mindfulness intervention for perinatal adolescents.

\section{RESULTS}

The search retrieved 561 articles and after removing duplicates, 481 titles and abstracts were scanned and 94 were selected for full article review (Figure 1). Duplicates were removed $(n=80)$ and 387 titles and abstracts were excluded based on: (1) 
incorrect target population ( $\mathrm{n}=125)$, (2) incorrect intervention $(n=173)$, and (3) incorrect methodology $(n=89)$. In addition, 78 full text articles did not meet eligibility criteria and were excluded due to: (1) mindfulness intervention did not fit criteria $(n=18)$, (2) target population was not specified $(n=24),(3)$ original data not presented $(n=12),(4)$ primary outcome data not reported $(n=18)$, and (5) no extractable data relevant to review $(n=6)$. Sixteen mindfulness-based studies in 15 publications with perinatal women met our inclusion criteria and were included in our review (Beattie, Hall, Biro, East, \& Lau, 2017; Byrne et al., 2013; Dunn, Hanieh, Roberts, \& Powrie, 2012; Duncan \& Bardacke, 2010; Duncan et al., 2017; Goodman et al., 2014; Guardino, Dunkel Schetter, Bower, Lu, \& Smalley, 2013; Krusche, Dymond, Murphy, \& Crane, 2018; Matvienko-Sikar \& Dockray, 2017; Muthukrishnan, Jain, Kohli, \& Batra, 2016; Pan et al., 2019; Townshend, Caltabiano, Powrie, \& O'Grady, 2018; Vieten \& Astin, 2008; Warriner, Crane, Dymond, \& Krusche, 2018; Woolhouse et al., 2014). Woolhouse et al. (2014) conducted a non-randomized trial and a randomized pilot-controlled trial as two separate studies within the same published article.

Out of the 16 studies, 15 were primarily conducted in high-income countries (World Bank Group, 2018), including five studies in the USA (Duncan \& Bardacke, 2010; Duncan et al., 2017; Goodman et al., 2014; Guardino et al., 2014; Vieten \& Astin, 2008;), three in the United Kingdom (Krusche et al., 2018; MatvienkoSikar \& Dockray, 2017; Warriner et al., 2018), five in Australia (Beattie et al., 2017; Byrne et al., 2013; Dunn et al., 2012; Townshend et al., 2018; Woolhouse et al., 2014), and one study in Taiwan (Pan et al., 2019). Only one study was conducted in a middle to low-income country, India (Muthukrishnan et al., 2016).

\section{Assessment of Bias}

Biases in the included studies were identified. Table 2 describes the quality of the perinatal adult studies, where nine of the 16 studies were assessed as having a low bias due to random sequence generation, allocation concealment, blinding of outcome assessment, blinding of participants and personnel, incomplete reporting of outcome data, and selective outcome reporting (Cochrane Editorial Resource Committee, N.D.); seven studies had unclear or high bias noted in these above areas of bias.
Table 3 describes the quality of these seven studies which were assessed as having a high or unclear bias due to allocation sequence, allocation concealment, baseline outcome measures, and/or baseline characteristics, incomplete outcome data due to attrition, knowledge of allocated intervention, no protection against contamination, selective outcome reporting, and independence from intervention changes are also of concern based on Data Extraction and Assessment Template (DEAT; Cochrane Public Health Group, N.D.) form (Byrne et al., 2013; Duncan \& Bardacke, 2010; Dunn et al., 2012; Goodman et al., 2014; Townshend et al., 2018; Warriner et al., 2018; Woolhouse et al., 2014 part 1).

\section{Mindfulness Intervention Outcomes}

Of the 16 studies included in this review which examined the perinatal adult population, 13 studies evaluated stress, nine studies explored anxiety and 14 studies reviewed depression. Six studies looked at all three outcomes (Byrne et al., 2013; Townshend et al., 2018; Vieten \& Astin, 2008; Warriner et al., 2018; Woolhouse et al., 2014). Anxiety was evaluated in nine studies and all nine studies found statistically significant decreases (Byrne et al., 2013; Duncan \& Bardacke, 2010; Goodman et al.,2014; Guardino et al., 2014; Townshend et al., 2018; Vieten \& Astin, 2008; Warriner et al., 2018; Woolhouse et al., 2014). Depression was evaluated in 14 studies and nine studies found a significant decrease in depression symptoms (Duncan et al., 2017; Duncan \& Bardacke, 2010; Dunn et al., 2012; Goodman et al., 2014; Krusche et al., 2018; Pan et al., 2019; Townshend et al., 2018; Warriner et al., 2018; Woolhouse et al., 2014; Table 4)

\section{Types of Treatment for Insomnia and Components of} Treatment

\section{Study Characteristics}

Table 5 describes the perinatal mindfulness intervention characteristics (components and design) with the adult population in the 16 studies reviewed. The components of the mindfulness program/intervention and format components were explored, in addition to the design including: (1) the number of weeks/length of the intervention, (2) the number of hours/duration of the intervention, (3) the setting in which the intervention was conducted, (4) 
the timing in which the intervention took place during gestation, (5) the number of contact points between the participant(s) and the intervention, and (6) the intervention provider/facilitator and their training.

Of the 16 studies, seven studies used a nonrandomised controlled trial design (Byrne et al., 2013; Dunn et al., 2012; Duncan \& Bardacke, 2010; Goodman et al., 2014; Townshend et al., 2018; Warriner et al., 2018; Woolhouse et al., 2014 - part 1), while nine were randomized controlled trials (Beattie et al., 2017; Duncan et al., 2017; Guardino et al., 2014; Krusche et al., 2018; Matvienko-Sikar \& Dockray, 2017; Muthukrishnan et al., 2016; Pan et al., 2019; Vieten \& Astin, 2008; Woolhouse et al., 2014 - part 2). In four studies, participants in the control group received usual care (i.e. standard medical care by a primary care provider) (Matvienko-Sikar \& Dockray, 2017; Muthukrishnan et al., 2016; Pan et al., 2019; Woolhouse et al., 2014 -part 2). Three RCT studies included usual care in addition to some form of generalized childbirth education (in a group, through readings, or discussion) (Beattie et al., 2017; Duncan et al., 2017; Guardino et al., 2014). The remaining nine quasi-experimental studies conducted pre-post comparisons with participants (Byrne et al., 2013; Dunn et al., 2012; Duncan \& Bardacke, 2010; Goodman et al., 2014; Krusche et al., 2018; Townshend et al., 2018; Vieten \& Astin, 2008; Warriner et al., 2018; Woolhouse et al., 2014 - part 2). Twelve studies had a sample size of 9 to 32 participants (Beattie et al., 2017; Byrne et al., 2013; Dunn et al., 2012; Duncan \& Bardacke, 2010; Duncan et al., 2017; Goodman et al., 2014; Guardino et al., 2014; Krusche et al., 2018; Matvienko-Sikar \& Dockray, 2017; Vieten \& Astin, 2008; Woolhouse et al., 2014 - parts 1 and 2). Four studies had a sample size ranging from 50 to 109 participants (Muthukrishnan et al., 2016; Pan et al., 2019; Townshend et al., 2018; Warriner et al., 2018).

The 16 studies included in the review were heterogeneous in outcome time points and measures (Table 4). The participants were recruited perinatally in all 16 studies. The target sample in all 16 studies were perinatal women, however two of the 16 studies did include partner participation (Byrne et al., 2013; Duncan \& Bardacke, 2010) and one study enrolled couples into the study together (Warriner et al., 2018). Three studies recruited during the first and second trimester (Guardino et al., 2014; MatvienkoSikar \& Dockray, 2017; Muthukrishnan et al., 2016), seven studies recruited during the second and third trimester (Beattie et al., 2017; Byrne et al., 2013; Dunn et al., 2012; Duncan \& Bardacke, 2010; Dunn et al., 2012; Pan et al., 2019; Warriner et al., 2018), and six studies recruited through all three trimesters (Goodman et al., 2014; Krusche et al., 2018; Townshend et al., 2018; Vieten \& Astin, 2008; Woolhouse et al., 2014).

Fourteen studies were conducted in-class, face-toface (Beattie et al., 2017; Byrne et al., 2013; Duncan \& Bardacke, 2010; Duncan et al., 2017; Dunn et al., 2012; Goodman et al., 2014; Guardino et al., 2014; Muthukrishnan et al., 2016; Pan et al., 2019; Townshend et al., 2018; Vieten \& Astin, 2008; Warriner et al., 2018; Woolhouse et al., 2014), while only two were delivered online (Krusche et al., 2018; Matvienko-Sikar \& Dockray, 2017). Childbirth education was incorporated into the mindfulness intervention in 11 out of 16 studies (Beattie et al., 2017; Byrne et al., 2013; Duncan \& Bardacke, 2010; Duncan et al., 2017; Dunn et al., 2012; Pan et al., 2019; Townshend et al., 2018; Vieten \& Astin, 2008; Warriner et al., 2018; Woolhouse et al., 2014) and five studies concentrated on mindfulness independent of childbirth education (Goodman et al., 2014; Guardino et al., 2014; Krusche et al., 2018; Matvienko-Sikar et al., 2016; Muthukrishnan et al., 2016). In 15 out of 16 studies, intervention material and practices consisted of homework and some form of mindfulness practice such as meditation, mindful movement and/or body scans (Beattie et al., 2017; Byrne et al., 2013; Duncan \& Bardacke, 2010; Duncan et al., 2017; Dunn et al., 2012; Goodman et al., 2014; Guardino et al., 2014; Krusche et al., 2018; Muthukrishnan et al., 2016; Pan et al., 2019; Townshend et al., 2018; Vieten \& Astin, 2008; Warriner et al., 2018; Woolhouse et al., 2014). Ten of the 15 studies which included homework incorporated an audio recording aid for mindfulness practice (Byrne et al., 2013; Duncan \& Bardacke, 2010; Duncan et al., 2017; Dunn et al., 2012; Goodman et al., 2014; Guardino et al., 2014; Pan et al., 2019; Vieten \& Astin, 2008; Woolhouse et al., 2014).

There was significant variance in the mindfulness intervention format (components and design, intervention duration, target sample), the setting in which sessions were conducted, timing (gestation), number of contacts, and the provider (Table 5$)$. All included studies evaluated a mindfulness intervention. Two of the 16 studies were general 
mindfulness-based interventions; not designed specifically for women in the perinatal period (Guardino et al., 2014; Krusche et al., 2018). Three studies were based on MBCT (Dunn et al., 2012; Goodman et al., 2014; Townshend et al., 2018). Four studies were based on MBCP (Duncan et al., 2017; Duncan \& Bardacke, 2010; Pan et al., 2019; Warriner et al., 2018). Two studies were based on MBSR (Byrne et al., 2013; Muthukrishnan et al., 2016). The majority of intervention formats, in 14 of 16 studies, included face-to-face mindfulness sessions which were provided in a group environment (Beattie et al., 2017; Byrne et al., 2013; Duncan \& Bardacke, 2010; Duncan et al., 2017; Dunn et al., 2012; Goodman et al., 2014; Guardino et al., 2014; Muthukrishnan et al., 2016; Pan et al., 2019; Townshend et al., 2018; Vieten \& Astin, 2008; Warriner et al., 2018; Woolhouse et al., 2014). Two studies were delivered via an online platform to be completed individually (Krusche et al., 2018; Matvienko-Sikar \& Dockray, 2017).

All 16 interventions were delivered across the perinatal period and consisted of multiple contacts. The intervention settings included hospital settings (Pan et al., 2019; Townshend et al., 2018; Vieten \& Astin, 2008; Woolhouse et al., 2014), university and/or academic settings (Duncan et al., 2017; Guardino et al., 2014; Goodman et al., 2014), an online platform accessed at home (Krusche et al., 2018; Matvienko-Sikar \& Dockray, 2017), and community settings: a tertiary health care and maternity services provider (Beattie et al., 2017), a clinic and off-site location (Duncan \& Bardacke, 2010), children's centers for expectant parents (Warriner et al., 2018), and in three studies the intervention settings were not reported (Byrne et al., 2013, Dunn et al., 2012; Muthukrishnan et al., 2016). In the majority of studies, the intervention was provided by a health care professional including midwives, mental health clinicians, psychologists, psychiatrists, or educators; in nine of the 16 studies, the provider was trained in mindfulness (Beattie et al., 2017; Byrne et al., 2013; Duncan \& Bardacke, 2010; Duncan et al., 2017; Goodman et al., 2014; Guardino et al., 2014; Pan et al., 2019; Vieten \& Astin, 2008; Warriner et al., 2018; Woolhouse et al., 2014).

Six of the 16 studies explored participant experiences (Byrne et al., 2013; Duncan \& Bardacke, 2010; Dunn et al., 2012; Goodman et al., 2014; Woolhouse et al., 2014). Byrne and colleagues (2013) determined participants felt a sense of community, were more active participants and decision makers during pregnancy and birth, and found the program very engaging (Byrne et al., 2013). Participants of the $M B C P$ intervention identified that MBCP was used to: (1) cope with stress, (2) stay in the present, (3) be aware of emotional reactivity, and (4) cope with the unexpected, during labour, delivery, and postpartum (Duncan \& Bardacke, 2010). Dunn and colleagues (2012) established themes at the six-week interviews: participants expressed that they: (1) stopped to think, (2) reflected, (3) embraced present (4) practiced acceptance, and (5) enjoyed sharing experiences (Dunn et al., 2012). The CALM pregnancy intervention study by Goodman et al., (2014) found that participants had learned: (1) specific skills to help anxiety, (2) connected and learned from others, (3) they were not alone, (4) acceptance and selfkindness, (5) to be less reactive, (6) to think differently, and (7) to develop insight into coping with anxiety. Woolhouse and colleagues (2014) conducted both a non-randomized trial and a pilot randomised control trial with a qualitative component; both found four main themes among participants. Participants stated that the MindBabyBody intervention: (1) helped to control destructive patterns: cognitive, emotional and behavioural, (2) improved interpersonal relationships, (3) quality of life, and (4) sleep. Qualitative reports from participants expand upon and support the quantitative findings which indicate the potential of mindfulness practices to improve women's mental health during the perinatal period.

Effective perinatal mindfulness components found in the 16 studies reviewed align with suggested practices for adolescent education program development; these components are presented in Table 6.

\section{DISCUSSION}

Positive trends in our review of 16 studies are encouraging and provide preliminary evidence of the effectiveness of mindfulness interventions. However, the current body of literature and empirical evidence surrounding mindfulness interventions does not provide conclusive evidence about the effectiveness of mindfulness interventions due to biases present in methodological designs and small sample sizes. Thus, further research is warranted to determine the effectiveness of mindfulness interventions delivered 
to perinatal adolescents to promote mental health, reducing stress, anxiety and depression.

It is noteworthy that resilience was only examined in one of the 16 studies (Duncan \& Bardacke, 2010). Conversely, resilience was a primary outcome measured in several studies which concentrated on mindfulness in adolescents (Broderick \& Frank, 2014; Tan \& Martin, 2012; Volanen et al., 2016; Zack et al., 2014). It would be of interest to measure resilience as an outcome in an adolescent perinatal intervention context, as the literature suggests that adolescent mothers endure hardship. Young women who become adolescent mothers are met with increased challenges in relation to the SDOH, when compared to mothers who delay childbearing (Hoffman \& Maynard, 2008; Raphael, 2014; Viner et al., 2012) and the SDOH in the children of adolescent mothers also suffer when compared to children of women who delay-childbearing (Hoffman \& Maynard, 2008; Planned Parenthood, 2014). Mindfulness training in adolescents promotes positive outcomes like resilience that can help break this cycle (Broderick \& Frank, 2014; Tan \& Martin, 2016; Volanen et al., 2016; Zack et al., 2014) and in such, extending mindfulness training is positively associated with adolescent mindfulness, self-esteem and resiliency (Broderick \& Frank, 2014; Tan \& Martin, 2016; Volanen et al., 2016; Zack et al., 2014). Building these skill sets perinatally through mindfulness training may increase the ability to cope with the SDOH challenges mother and child will face in the future. Recent literature demonstrates that resilience may help these young women and their children access the SDOH in their future (Hoffman \& Maynard, 2008; Planned Parenthood, 2014; Raphael, 2014; Tan \& Martin, 2012; Viner et al., 2012).

It is evident that adolescent learning preferences and developmental needs vary from adults (Anderson \& McGuiness, 2008; Klein, 2005; Low et al., 2003; Mercer, 1995; Sauls, 2004, 2010). The findings of effective mindfulness intervention components and design in this review were consistent with those found by Dhillon et al. (2017), Hall et al. (2016), Matvienko-Sikar et al. (2016), Shi \& MacBeth (2017) and Lever Taylor et al. (2016) in the perinatal population and with Cheang et al. (2019), Kostova et al. (2019) and McKeering and Hwang (2019) who conducted systematic reviews of mindfulness interventions with the adolescent population.

\section{Recommendations for Designing Mindfulness Intervention to Perinatal Adolescents}

While there had been development in designing mindfulness interventions for children and adults, currently, there is no known protocol for designing mindfulness interventions for perinatal adolescents (Kostova et al., 2019). In alignment with suggested practices for adolescent education, the components and design of these interventions may have the capacity to be integrated into existing mindfulness programs and adapted to benefit perinatal adolescents. Based in foundational literature regarding the appropriateness of web-based applications for adolescents, it is recommended that current childbirth education providers be aware of freely available web-based resources for adolescent mothers, such as Mind the Bump, Smiling Minds or the Mindfulness for Pregnancy app, as pre-existing mindfulness training programs that can be integrated into their established perinatal education. In regard to in-class mindfulness interventions, it is recommended that the facilitator have a knowledge of the adolescent developmental stage, that the session have a duration of 90 minutes or less, be interactive and engaging with a focus on reflection, and make support training for the parents/caregivers and/or partner of perinatal adolescents available when required. Future research should also include how to tailor interventions to reduce attrition among vulnerable adolescents, as this population's reduced access to SDOH tends to negatively effect study retention (Pyatak et al., 2013). In addition, the perinatal population is also disposed to high attrition (Beattie et al., 2017; Duncan et al., 2017; Dunn et al., 2012; Guardino et al., 2014; Townshend et al., 2018; Woolhouse et al., 2014) often due to barriers such as, demographic factors, insufficient time to participate/complete the study, and/or the unpredictability of childbirth and/or medical complications (Coleman-Phox et al., 2013; Frew et al., 2014).

\section{Limitations of this Review}

The findings of this systematic review illustrate significant methodological issues with the 16 studies explored. Limitations of our findings were due to concerns with methodological quality of the included studies based on: (1) small, convenience samples; (2) high bias, a lack of active-controls, self-reported measures, self-selection, and high attrition; and (3) 
heterogeneity in measurements, programs, format, settings, and providers of included studies making it difficult to draw definitive conclusions. In addition, this study was conducted by a single reviewer as part of a master's project. While screening, coding, and analysis by two reviewers is recommended, the reviewer (KK) was closely supervised by a more experienced co-investigator (JAD) who sought consultation with a review methodologist (GB). These strategies helped to mitigate the risk that some studies were missed (Waffenschmidit et al., 2019). In addition, adolescent mindfulness interventions were not incorporated specifically into the search strategy; however, these studies would have been located through the broader search terms used. Finally, it should be considered that only perinatal mindfulness intervention components found to be effective were included, nevertheless, for the purposes of finding the components of effective interventions this strategy was appropriate.

\section{CONCLUSION}

In conclusion, this review demonstrates that mindfulness interventions are a non-invasive, nonpharmacological approach found to show positive trends towards promoting perinatal mental health among adults, which can be adapted for perinatal adolescents. Mindfulness interventions are preventative practices that can be pursued independently, are cost-effective, and offer transferable benefits (Cullen, 2011).

\section{REFERENCES}

Anderson, C., \& McCarley, M. (2013). Psychological birth trauma in adolescents experiencing an early birth. MCN, The American Journal of Maternal/Child Nursing, 38(3), 170-176. https://doi.org/10.1097/NMC.0b013e31826 f6cad

Anderson, C., \& McGuinness, T. (2008). Do teenage mothers experience childbirth as traumatic? Journal of Psychosocial Nursing and Mental Health Services, 46(4), 21-24. https://doi.org/10.3928/0279369520080401-01

Beattie, J., Hall, H., Biro, M., East, C., \& Lau, R. (2017). Effects of mindfulness on maternal stress, depressive symptoms and awareness of present moment experience: A pilot randomised trial. Midwifery, 50, 174-183. https://doi.org/10.1016/j.midw.2017.04.00 6

Broderick, P., \& Frank, J. (2014). Learning to BREATHE: An intervention to foster mindfulness in adolescence. New Directions for Youth Development, 142, 31-44. https://doi.org/10.1002/yd.20095

Budden, A., Chappelle, J., Comiré, S., Foroutani, S., Jones, K., Misek, D. et al. (2016). My life, my voice: The experience of young parents in Durham Region [Ebook] (1-98). Oshawa: Young Parent Community Coalition of Durham. http://durham.ca/mylifemyvoice

Byrne, J., Hauck, Y., Fisher, C., Bayes, S., \& Schutze, R. (2013). Effectiveness of a mindfulness-based childbirth education pilot study on maternal self-efficacy and fear of childbirth. Journal of Midwifery and Women's Health, 59(2), 192197. https://doi.org/10.1111/jmwh.12075

Campbell, M., Katikireddi, S., Sowden, A., McKenzie, J., \& Thomson, H. (2018). Improving conduct and reporting of narrative synthesis of quantitative data (ICONS-Quant): Protocol for a mixed methods study to develop a reporting guideline, BMJ Open, 8(2), 020064. https://doi.org/10.1136/bmjopen-2017020064

Cheang, R., Gillions, A., \& Sparkes, E. (2019). Do mindfulness-based interventions increase empathy and compassion in children and adolescents: A systematic review. Journal of Child and Family Studies, 28(7), 1765-1779. https://doi.org/10.1007/s10826-019-014139

Cochrane Editorial Resource Committee (N.D). Cochrane pregnancy and childbirth group data extraction form. Retrieved from https://pregnancy.cochrane.org

Cochrane Public Health Group (N.D.) Data Extraction and Assessment Template. Retrieved From: https://ph.cochrane.org/sites/ph.cochrane. org/files/public/uploads/CPHG\%20Data\%20 extraction\%20template_0.docx

Coleman-Phox, K., Laraia, B., Adler, N., Vieten, C., Thomas, M., \& Epel, E., (2013). Recruitment and retention of pregnant women for a behavioral intervention: Lessons from the Maternal Adiposity, Metabolism, and Stress (MAMAS) study. Preventing Chronic Disease, 10 , 1-7. https://doi.org/10.5888/pcd10.120096 
Corcoran, J. (2016). Teenage pregnancy and mental health. Societies, 6(3), 1-9. https://doi.org/10.3390/soc6030021

Cullen, M. (2011). Mindfulness-based interventions: An emerging phenomenon. Mindfulness, 2(3), 186-193. https://doi.org/10.1007/s12671-011-0058-1

Dhillon, A., Sparkes, E., \& Duarte, R. (2017). Mindfulness-based interventions during pregnancy: A systematic review and metaanalysis. Mindfulness, 8(6), 1421-1437. https://doi.org/10.1007/s12671-017-0726-x

Duncan, L., Cohn, M., Chao, M., Cook, J., Riccobono, J., \& Bardacke, N. (2017). Benefits of preparing for childbirth with mindfulness training: A randomized controlled trial with active comparison. BMC Pregnancy and Childbirth, 17(140), 1-11. https://doi.org/10.1186/s12884-017-1319-3

Duncan, L., \& Bardacke, N. (2010). Mindfulness-based childbirth and parenting education:

Promoting family mindfulness during the perinatal period. Journal of Child and Family Studies, 19(2), 190-202. https://doi.org/10.1007/s10826-009-9313-7

Dunn, C., Hanieh, E., Roberts, R., \& Powrie, R. (2012). Mindful pregnancy and childbirth:

Effects of a mindfulness-based intervention on women's psychological distress and wellbeing during the perinatal period. Archives of Women's Mental Health.15, 139143. https://doi.org/10.1007/s00737-0120264-4

Frew, P., Saint-Victor, D., Isaacs, M., Kim, S., Swamy, G., Sheffield, J., Edwards, K., Villafana, T., Kamagate, O., \& Ault, K. (2014). Recruitment and retention of pregnant women into clinical research trials: An overview of challenges, facilitators, and best practices. Clinical Infectious Diseases, 59(7), 400-407. https://doi.org/10.1093/cid/ciu726

Goodman, J., Guarino, A., Chenausky, K., Klein, L., Prgaer, J., Petersen, R., Forget, A., \& Freeman, M. (2014). CALM Pregnancy: Results of a pilot study of mindfulness-based cognitive therapy for perinatal anxiety. Archive of Women's Mental Health. 17, 373387. https://doi.org/10.1007/s00737-0130402-7

Gu, J., Strauss, C., Bond, R., \& Cavanagh, K. (2015). How do mindfulness-based cognitive therapy and mindfulness-based stress reduction improve mental health and wellbeing? A systematic review and metaanalysis of mediation studies. Clinical Psychology Review, 37, 1-12. https://doi.org/10.1016/j.cpr.2015.01.006

Guardino, C., Dunkel Schetter, C., Bower, J., Lu, M., \& Smalley, S. (2013). Randomised controlled pilot trial of mindfulness training for stress reduction during pregnancy. Psychology \& Health, 29(3), 334-349. https://doi.org/10.1080/08870446.2013.85 2670

Hall, H., Beattie, J., Lau, R., East, C., \& Biro, M. (2016). The effectiveness of mindfulness training on perinatal mental health: A systematic review. Women and Birth, 29(1), 62-71.

https://doi.org/10.1016/j.imr.2015.04.233

Higgins, J.P., \& Green, S. (2011). Cochrane handbook for systematic reviews of interventions: Wiley Online Library.

Hoffman, D., \& Maynard, R. (2008). Kids having kids: Economic costs and social consequences of teen pregnancy, 2nd edition. Washington, DC: The Urban Institute Press.

Hoffmann, T., Glasziou, P., Boutron, I., Milne, R., Perera, R., Moher, D., Altman, D., Barbour, V., Macdonald, H., Johnston, M., Lamb, S., Dixon-Woods, M., McCulloch, P., Wyatt, J., Chan, A., \& Michie, S. (2014). Better reporting of interventions: Template for intervention description and replication (TIDieR) checklist and guide. British Medical

Journal, 348 , 1687-1687. https://doi.org/10.1136/bmj.g1687

Kabat-Zinn, J. (2003). Mindfulness-based interventions in context: Past, present, and future. Clinical Psychology: Science and Practice, 10(2), 144-156. https://doi.org/10.1093/clipsy.bpg016

Kingston, D., Heaman, M., Fell, D., \& Chalmers, B. (2012). Comparison of adolescent, young adult, and adult women's maternity experiences and practices. Paediatrics, 129(5), 1228-1237. https://doi.org/10.1542/peds.2011-1447

Kostova, Z., Levin, L., Lorberg, B., \& Ziedonis, D. (2019). Mindfulness-based interventions for Adolescent's with mental health conditions: A systematic review of the research literature. Journal of Child and Family Studies, 28, 2633-2649. 
https://doi.org/10.1007/s10826-019-014777

Krusche, A., Dymond, M., Murphy, S., \& Crane, C. (2018). Mindfulness for pregnancy: A randomised controlled study of online mindfulness during pregnancy. Midwifery, 65, 51-57. https://doi.org/10.1016/j.midw.2018.07.00 5

Lever Taylor, B., Cavanagh, K., \& Strauss, C. (2016). The effectiveness of mindfulness-based interventions in the perinatal period: A systematic review and meta-analysis. PLOS ONE, 11(5), 0155720. https://doi.org/10.1371/journal.pone.0155 720

Logsdon, M., Barone, M., Lynch, T., Robertson, A., Myers, J., Morrison, D. et al. (2013). Testing of a prototype Web based intervention for adolescent mothers on postpartum depression. Applied Nursing Research, 26(3), 143-145. https://doi.org/10.1016/j.apnr.2013.01.005

Matvienko-Sikar, K., \& Dockray, S. (2017). Effects of a novel positive psychological intervention on prenatal stress and well-being: A pilot randomised controlled trial. Women and Birth, 30(2), 111-118. https://doi.org/10.1016/j.wombi.2016.10.0 03

Matvienko-Sikar, K., Lee, L., Murphy, G., \& Murphy, L. (2016). The effects of mindfulness interventions on prenatal well-being: A systematic review. Psychology \& Health, 31(12),

415-434. https://doi.org/10.1080/08870446.2016.12 20557

McKeering, P., \& Hwang, Y. (2019). A systematic review of mindfulness-based school interventions with early adolescents. Mindfulness, 10(4), 593-610. https://doi.org/10.1007/s12671-018-0998-9

Mercer, R. T. (1995). Becoming a mother. New York: Springer. Muthukrishnan, S., Jain, R., Kohli, S., \& Batra, S. (2016). Effect of mindfulness meditation on perceived stress scores and autonomic function tests of pregnant Indian women. Journal of Clinical and Diagnostic Research, $10(4), \quad 58$. https://doi.org/10.7860/JCDR/2016/16463. 7679
O’Mara-Eves, A., Brunton, G., McDaid, D., Oliver, S., Kavanagh, J., Jamal, F., Matosevic, T., Harden, A., \& Thomas, J. (2013). Community engagement to reduce inequalities in health: A systematic review, meta-analysis and economic analysis. Public Health Research, 1(4), 1-526. https://doi.org/10.3310/phr01040

Pan, W., Gau, M., Lee, T., Jou, H., Liu, C., \& Wen, T. (2019). Mindfulness-based programme on the psychological health of pregnant women. Women and Birth, 32(1), 102-109. https://doi.org/10.1016/j.wombi.2018.04.0 18

Pyatak, E., Blanche, E., Garber, S., Diaz, J., Blanchard, J., Florindez, L., \& Clark, F. (2013). Conducting intervention research among underserved populations: Lessons learned and recommendations for researchers. Archives of Physical Medicine and Rehabilitation, 94(6), 1190-1198. https://doi.org/10.1016/j.apmr.2012.12.00 9

Raphael, D. (2014). Social determinants of children's health in Canada: Analysis and implications. International Journal of Child, Youth and Family Studies, 5(2), 220-239. https://doi.org/10.18357/ijcyfs.raphaeld.52 2014

Registered Nurses' Association of Ontario (RNAO) (2010). Clinical best practice guidelines: Enhancing healthy adolescent development. Toronto. Retrieved 07/29/19 from https://rnao.ca/sites/rnao-

ca/files/Enhancing_Healthy_Adolescent_De velopment.pdf

Sauls, D. (2004). Adolescents' perception of support during labour. The Journal of Perinatal Education, 13(4), 36-42. https://doi.org/10.1624/105812404X6216

Scott, K., Klaus P., \& Klaus, M. (1999). The obstetrical and postpartum benefits of continuous support during childbirth. Journal of Women's Health and Gender-Based Medicine, 8(10), 1257-1264. https://doi.org/10.1089/jwh.1.1999.8.1257

Shi, Z., \& MacBeth, A. (2017). The effectiveness of mindfulness-based interventions on maternal perinatal mental health outcomes: A systematic review. Mindfulness, 8(4), 823847. https://doi.org/10.1007/s12671-0160673-y 
Siegel, R. S., \& Brandon, A. R. (2014). Adolescents, pregnancy, and mental health. Journal of

Paediatric and Adolescent Gynaecology, 27(3), 138150.

https://doi.org/10.1016/j.jpag.2013.09.008

Statistics Canada (2017). Life in the fast lane: How are Canadian's managing? Retrieved from https://www150.statcan.gc.ca/n1/dailyquotidien/171114/dq171114aeng.htm?HPA=1

Statistics Canada. (2019). Maternal mental health in Canada 2018-2019. Retrieved from: https://www150.statcan.gc.ca/n1/dailyquotidien/190624/dq190624b-eng.htm

Statistics Canada. (2021). Live births by age of mother. Retrieved from: https://www150.statcan.gc.ca/t1/tbl1/en/t v.action?pid=1310041601

Stinson, J., Wilson, R., Gill, N., Yamada, J., \& Holt, J. (2009). A systematic review of internetbased self-management interventions for youth with health conditions. Journal of Pediatric Psychology, 34(5), 495-510. https://doi.org/10.1093/jpepsy/jsn115

Tan, L., \& Martin, G. (2012). Mind full or mindful: A report on mindfulness and psychological health in healthy adolescents. International Journal of Adolescence and Youth, 21(1), 64 74.

https://doi.org/10.1080/02673843.2012.70 9174

Tang, Y., Holzel, B., \& Posner, M. (2015). The neuroscience of mindfulness meditation. Nature Reviews Neuroscience, 16, 213-225. https://doi.org/10.1007/978-3-319-46322-3

Townshend, K., Caltabiano, N., Powrie, R., \& O'Grady, $H$. (2018). A preliminary study

investigating the effectiveness of the caring for body and mind in pregnancy (CBMP) in reducing perinatal depression, anxiety and stress. Journal of Child and Family Studies, 27(5), 1556-1566. https://doi.org/10.1007/s10826-017-0978-z

Vieten, C., \& Astin, J. (2008). Effects of a mindfulnessbased intervention during pregnancy on prenatal stress and mood: Results of a pilot study. Archives of Women's Mental Health, 11, 67-74. https://doi.org/10.1007/s00737008-0214-3

Viner, R., Ozer, E., Denny, S., Marmot, M., Resnick, M., Fatusi, A., \& Currie, C. (2012). Adolescence and the social determinants of health.
Adolescent Health 2, 379, 1641-1652. https://doi.org/10.1016/S0140-

6736(12)60149-4

Volanen, S., Lassander, M., Hankonen, N., Santalahti, P., Hintsanen, M., Simonsen, N., Raevouri, A., Mullola, S., Vahlberg, T., But, A., \& Suminen, S. (2016). Health learning mind - a school-based mindfulness and relaxation program: A study protocol for a cluster randomized controlled trial. BMC Psychology, 4(35), 1-10. https://doi.org/10.1186/s40359-016-0142-3

Waffenschmidt, S., Knelangen, M., Sieben, W., Bühn, S., \& Pieper, D. (2019). Single screening versus conventional double screening for study selection in systematic reviews: a methodological systematic review. BMC Medical Research Methodology, 19(1), 1-9. https://doi.org/10.1186/s12874-019-0782-0

Warriner, S., Crane, C., Dymond, M., \& Krusche, A. (2018). An evaluation of mindfulness- based childbirth and parenting courses for pregnant women and prospective fathers/partners within the UK NHS (MBCP4-NHS). Midwifery, 64, 1-10. https://doi.org/10.1016/j.midw.2018.05.00 4

Woolhouse, H., Mercuri, K., Judd, F., \& Brown, S. (2014). Antenatal mindfulness intervention to reduce depression, anxiety and stress: a pilot randomized controlled trial of the MindBabyBody program in an Australian tertiary maternity hospital. BMC Pregnancy and Childbirth, 14(369), 1-16. https://doi.org/10.1186/s12884-014-0369-z

World Bank Group. (2018). World bank country and lending groups. Retrieved from https://datahelpdesk.worldbank.org/knowl edgebase/articles/906519

Zaers, S., Waschke, M., \& Ehlert, U. (2008). Depressive symptoms and symptoms of post-traumatic stress disorder in women after childbirth. Journal of Psychosomatic Obstetrics and Gynecology, 29(1), 61-71. https://doi.org/10.1080/016748207018043 24

Zack, S., Saekow, J., Kelly, M., \& Radke, A. (2014). Mindfulness-based interventions for youth. Journal of Rational-Emotive and CognitiveBehaviour Therapy, 32(1), 44-56. https://doi.org/10.1007/s10942-014-01792. 
Table 1. Search terms for perinatal mindfulness for women

1. mindful*.ab,ti,kf.

2. (mindfulness-based or mindfulness based).ab,ti,kf.

3. or/1-2

4. women .ab,ti,kf.

5. mother*.ab,ti,kf.

6. (mom or moms or mommy).ab,ti,kf.

7. maternal. ab,ti,kf.

8. adolescent*.ab,ti,kf.

9. or/4-8

10. perinatal*.ab,ti,kf.

11. prenatal*.ab,ti,kf.

12. pregnan*.ab,ti,kf.

13. antenatal*.ab,ti,kf.

14. (postpartum or post-partum).ab,ti,kf.

15. (childbirth or child birth).ab,ti,kf.

16. or/10-15

17. (mental adj3(health or wellness or disorder or illness).ab,ti,kf.

18. (mood adj2 disorder).ab,ti,kf.

19. (stress* or anxiety or depressi* or resilen* or fear or pain).ab,ti,kf.

20. or/17-19

21. (educat* or program* or practice* or intervention* or train* or support* or trial* or control* or experiment*).ab,ti,kf.

22. 20 and 21

23. 16 and 22

24. 9 and 23

25. 3 and 24 
Figure 1. PRISMA 2009 Study Identification and Select

Records identified through database search $(n=561)$

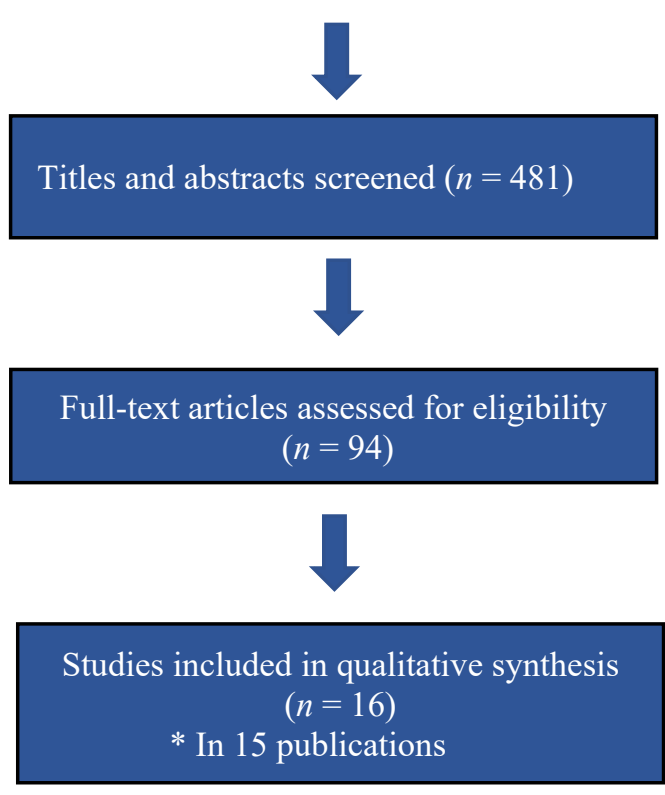

Duplicates removed $(n=80)$

$(n=387)$ Excluded on basis of title/abstract:

$n=125$ incorrect target population

$n=173$ incorrect intervention

$n=89$ incorrect methodology

\section{$(n=78)$ Excluded on basis of full text:}

$n=18$ mindfulness intervention did not fit criteria

$n=24$ target population was not specified

$n=12$ original data not presented

$n=18$ primary outcome data not reported

$n=6$ no extractable data relevant to review 
International Health Trends and Perspectives

Table 2. Assessment of risk of bias for perinatal adult (PCG Form)

\begin{tabular}{|c|c|c|c|c|c|c|c|}
\hline Author, year & Design & $\begin{array}{c}\text { Random } \\
\text { sequence } \\
\text { generation }\end{array}$ & $\begin{array}{c}\text { Allocation } \\
\text { concealment }\end{array}$ & $\begin{array}{l}\text { Blinding of } \\
\text { outcome } \\
\text { assessment }\end{array}$ & $\begin{array}{c}\text { Blinding of participants } \\
\text { and personnel }\end{array}$ & $\begin{array}{l}\text { Incomplete outcome } \\
\text { data }\end{array}$ & $\begin{array}{l}\text { Selective outcome } \\
\text { reporting }\end{array}$ \\
\hline Beattie et al. (2017) & ${ }^{*} \mathrm{RCT}$ & Low & Low & Low & Low & Unclear & Low \\
\hline Duncan et al. (2017) & ${ }^{*} \mathrm{RCT}$ & Low & Low & Low & Low & Low & Low \\
\hline Guardino et al. (2014) & ${ }^{*} \mathrm{RCT}$ & Low & Unclear & Unclear & Unclear & Low & Low \\
\hline Krusche et al. (2018) & ${ }^{*} \mathrm{RCT}$ & Low & Low & Unclear & Low & Low & Low \\
\hline $\begin{array}{l}\text { Matvienko-Sikar \& } \\
\text { Dockray (2017) }\end{array}$ & ${ }^{*} \mathrm{RCT}$ & Low & Low & Unclear & Low & Low & Low \\
\hline $\begin{array}{l}\text { Muthukrishnan et al. } \\
\qquad(2016)\end{array}$ & ${ }^{*} \mathrm{RCT}$ & Unclear & Unclear & Low & Low & Low & Low \\
\hline Pan et al. (2019) & ${ }^{*} \mathrm{RCT}$ & Low & Low & Unclear & Low & Low & Low \\
\hline Vieten \& Astin (2008) & ${ }^{*} \mathrm{RCT}$ & Low & Unclear & Unclear & Unclear & Low & Low \\
\hline $\begin{array}{l}\text { Woolhouse et al. (2014 } \\
\text { part 2) }\end{array}$ & ${ }^{*} \mathrm{RCT}$ & Low & Low & Unclear & Unclear & Low & Low \\
\hline
\end{tabular}

${ }^{*}$ RCT $=$ Randomized Controlled Trial 
Table 3. Assessment of risk of bias for perinatal adult population (DEAT Form)

\begin{tabular}{|c|c|c|c|c|c|c|c|c|c|c|}
\hline $\begin{array}{c}\text { Author, } \\
\text { year }\end{array}$ & Design & $\begin{array}{l}\text { Allocation } \\
\text { sequence }\end{array}$ & $\begin{array}{c}\text { Allocation } \\
\text { concealment }\end{array}$ & $\begin{array}{l}\text { Baseline } \\
\text { outcome } \\
\text { measures }\end{array}$ & $\begin{array}{c}\text { Baseline } \\
\text { characteristics }\end{array}$ & $\begin{array}{l}\text { Incomplete } \\
\text { outcome data } \\
\text { addressed }\end{array}$ & $\begin{array}{l}\text { Knowledge } \\
\text { of allocated } \\
\text { intervention }\end{array}$ & $\begin{array}{c}\text { Protection } \\
\text { against } \\
\text { contamination }\end{array}$ & $\begin{array}{l}\text { Selective } \\
\text { outcome } \\
\text { reporting }\end{array}$ & $\begin{array}{l}\text { Independence } \\
\text { from } \\
\text { intervention } \\
\text { changes }\end{array}$ \\
\hline $\begin{array}{l}\text { Byrne et al. } \\
(2013)\end{array}$ & $* Q E$ & No & No & Yes & No & No & No & No & Yes & No \\
\hline $\begin{array}{c}\text { Duncan \& } \\
\text { Bardacke } \\
(2010)\end{array}$ & ${ }^{*} \mathrm{QE}$ & No & No & No & No & No & No & No & Yes & No \\
\hline $\begin{array}{c}\text { Dunn et al. } \\
(2012)\end{array}$ & ${ }^{*} \mathrm{QE}$ & No & No & Yes & Yes & No & No & No & Yes & No \\
\hline $\begin{array}{c}\text { Goodman } \\
\text { et al. (2014) }\end{array}$ & $* Q E$ & No & No & Yes & Yes & No & No & No & Yes & No \\
\hline $\begin{array}{l}\text { Townshend } \\
\text { et al. (2018) }\end{array}$ & $* Q E$ & No & No & Yes & Yes & No & No & No & Yes & No \\
\hline $\begin{array}{c}\text { Warriner et } \\
\text { al. (2018) }\end{array}$ & $* Q E$ & No & No & Yes & No & No & No & No & Yes & No \\
\hline $\begin{array}{l}\text { Woolhouse } \\
\text { et al. (2014 } \\
\text { part 1) }\end{array}$ & $* Q E$ & No & No & Yes & Yes & No & No & No & Yes & No \\
\hline
\end{tabular}

*QE $=$ Quasi-Experimental 
Table 4. Perinatal mindfulness intervention outcomes with adult population

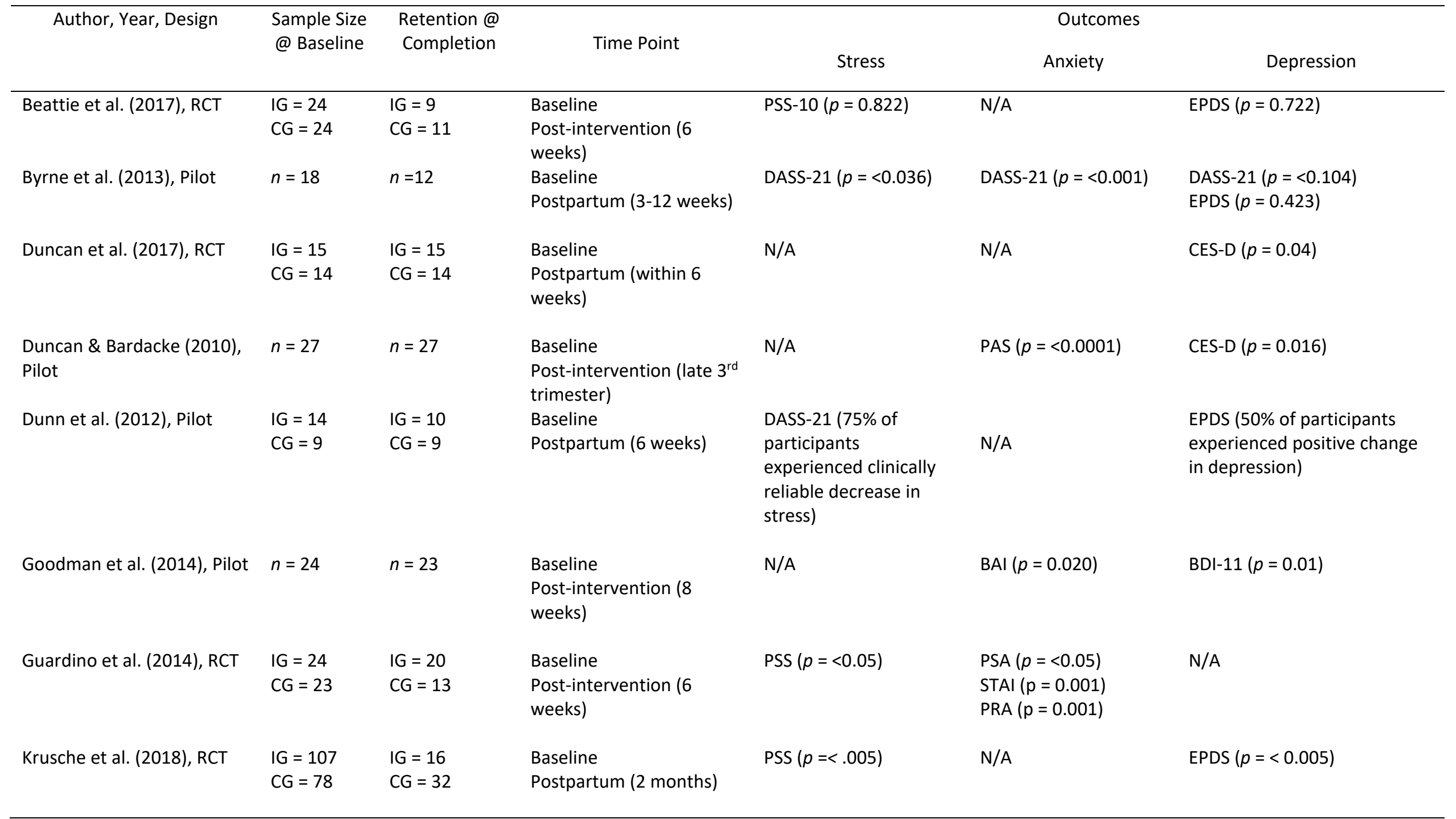




\begin{tabular}{|c|c|c|c|c|c|c|}
\hline $\begin{array}{l}\text { Matvienko-Sikar \& Dockray } \\
\text { (2017), RCT }\end{array}$ & $\begin{array}{l}I G=32 \\
C G=14\end{array}$ & $\begin{array}{l}I G=24 \\
C G=12\end{array}$ & $\begin{array}{l}\text { Baseline } \\
\text { Post-intervention ( } 3 \\
\text { weeks) }\end{array}$ & $\operatorname{PDQ}(p=0.04)$ & $\mathrm{N} / \mathrm{A}$ & $\operatorname{EPDS}(p=0.97)$ \\
\hline $\begin{array}{l}\text { Muthukrishnan et al. } \\
\text { (2016), RCT }\end{array}$ & $\begin{array}{l}I G=37 \\
C G=37\end{array}$ & $\begin{array}{l}I G=37 \\
C G=37\end{array}$ & $\begin{array}{l}\text { Baseline } \\
\text { Post-intervention ( } 5 \\
\text { weeks) }\end{array}$ & $\operatorname{PSS}(p=<0.001)$ & $N / A$ & $\mathrm{~N} / \mathrm{A}$ \\
\hline Pan et al. (2019), RCT & $\begin{array}{l}\mathrm{IV}=52 \\
\mathrm{CG}=52\end{array}$ & $\begin{array}{l}I G=51 \\
C G=45\end{array}$ & $\begin{array}{l}\text { Baseline } \\
\text { Postpartum ( } 36 \text { weeks } \\
\text { gestation) }\end{array}$ & $\operatorname{PSS}(p=<0.01)$ & $N / A$ & $\operatorname{EPDS}(p=0.007)$ \\
\hline $\begin{array}{l}\text { Townshend et al. (2018), } \\
\text { Pilot }\end{array}$ & $n=109$ & $n=109$ & $\begin{array}{l}\text { Baseline } \\
\text { Post-intervention ( } 8 \\
\text { weeks) }\end{array}$ & DASS-21 $(p=<0.01)$ & $\begin{array}{l}\text { DASS-21 }(p=0.05) \\
\text { PASS }(p=<0.01)\end{array}$ & $\begin{array}{l}\text { DASS-21 }(p=<0.01) \\
\operatorname{EPDS}(p=<0.01)\end{array}$ \\
\hline Vieten \& Astin (2008), RCT & $\begin{array}{l}I G=13 \\
C G=18\end{array}$ & $\begin{array}{l}I G=13 \\
C G=18\end{array}$ & $\begin{array}{l}\text { Baseline } \\
\text { Post-intervention (10 } \\
\text { weeks) }\end{array}$ & $\operatorname{PSS}(p=0.35)$ & $\operatorname{STAI}(p=<0.04)$ & CES-D $((p=0.06)$ \\
\hline Warriner et al. (2018), Pilot & $\begin{array}{l}\text { Mothers } \\
n=64 \\
\text { Partners } \\
n=36\end{array}$ & $\begin{array}{l}\text { Mothers } \\
n=36 \\
\text { Partners } \\
n=19\end{array}$ & $\begin{array}{l}\text { Baseline } \\
\text { Post-intervention ( } 4 \\
\text { weeks) }\end{array}$ & $\begin{array}{l}\text { Mothers PSS ( } p= \\
<0.001) \\
\text { Partners PPS ( } p=0.057)\end{array}$ & $\begin{array}{l}\text { Mothers GAD-7 } \\
(p=<0.001) \\
\text { Partners GAD-7 } \\
(p=0.016)\end{array}$ & $\begin{array}{l}\text { Mothers EPDS ( } p=<0.0001) \\
\text { Partners EPDS ( } p=0.028)\end{array}$ \\
\hline $\begin{array}{l}\text { Woolhouse et al. (2014), } \\
\text { Pilot-part 1: Non-RCT }\end{array}$ & $n=20$ & $n=11$ & $\begin{array}{l}\text { Baseline } \\
\text { Post-intervention ( } 8 \\
\text { weeks) }\end{array}$ & $\begin{array}{l}\operatorname{DASS}(p=0.07) \\
\operatorname{PSS}(p=0.09)\end{array}$ & $\begin{array}{l}\operatorname{STAI}(p=0.04) \\
\operatorname{DASS}(p=0.20)\end{array}$ & $\begin{array}{l}\text { CES-D }(p=0.04) \\
\text { DASS }(p=0.01)\end{array}$ \\
\hline $\begin{array}{l}\text { Woolhouse et al. (2014), } \\
\text { part } 2 \text { : Pilot RCT }\end{array}$ & $\begin{array}{l}\mathrm{IG}=17 \\
\mathrm{CG}=15\end{array}$ & $\begin{array}{l}\mathrm{IG}=13 \\
\mathrm{CG}=10\end{array}$ & $\begin{array}{l}\text { Baseline } \\
\text { Post-baseline ( } 8 \text { weeks) }\end{array}$ & $\begin{array}{l}\operatorname{DASS}(p=0.33) \\
\operatorname{PSS}(p=0.60)\end{array}$ & $\begin{array}{l}\operatorname{STAI}(p=0.52) \\
\operatorname{DASS}(p=0.02)\end{array}$ & $\begin{array}{l}\text { CES-D }(p=0.47) \\
\text { DASS }(p=0.15)\end{array}$ \\
\hline
\end{tabular}

IG = Intervention Group; CG = Control Group; EPDS = Edinburgh Post Natal Depression Scale; PSS = Perceived Stress Scale; CES-D: Centre for Epidemiological Studies - Depression Scale; DASS-21 = Depression, Anxiety \& Stress Scale; STAI = State-Trait Anxiety Scale; PAS = Pregnancy Anxiety Scale; BAI = Beck Anxiety Inventory; GAD-7 = General Anxiety Disorder; BDI-II = Beck Depression Inventory; PSA = Pregnancy Specific Anxiety scale; PRA = Pregnancy Related Anxiety Scale; RCT = Randomized Controlled Trial; PSS-10= Perceived Stress Scale PSS-10; PDQ = Pregnancy Distress Scale 
International Health Trends and Perspectives

Table 5. Perinatal mindfulness intervention characteristics (components and design) with adult population

\begin{tabular}{|c|c|c|c|c|c|c|c|}
\hline Study & Program & Format (components and design) & Weeks/Hours & $\begin{array}{l}\text { Setting } \\
\text { (sessions } \\
\text { conducted) }\end{array}$ & $\begin{array}{l}\text { Timing of } \\
\text { Perinatal } \\
\text { Intervention } \\
\text { (Gestation) }\end{array}$ & $\begin{array}{l}\text { Number of } \\
\text { contacts }\end{array}$ & Provider \\
\hline $\begin{array}{l}\text { Beattie et al. } \\
(2017)\end{array}$ & $\begin{array}{l}\text { Mindfulness in } \\
\text { Pregnancy } \\
\text { Program (MiPP) }\end{array}$ & $\begin{array}{l}\text { Face to Face (group) } \\
\text { In-class: childbirth education and } \\
\text { mindfulness practice. Homework: } \\
\text { meditation and readings }\end{array}$ & 8 weeks $/ 2$ hours & Community & $\begin{array}{l}2^{\text {nd }} \text { and } 3^{\text {rd }} \\
\text { trimester }\end{array}$ & $\begin{array}{l}\text { Multiple } \\
\text { contacts }\end{array}$ & $\begin{array}{l}\text { Midwife researcher/ investigator } \\
\text { (Jill Beattie) trained in } \\
\text { Mindfulness-integrated Cognitive } \\
\text { Behavioural Therapy (MiCBT) }\end{array}$ \\
\hline $\begin{array}{l}\text { Australia } \\
\text { Byrne et al. } \\
\text { (2013) } \\
\text { Australia }\end{array}$ & $\begin{array}{l}\text { Mindfulness-Based } \\
\text { Childbirth } \\
\text { Education (MBCE) }\end{array}$ & $\begin{array}{l}\text { Face to face (group) } \\
\text { In-class: childbirth education and } \\
\text { mindfulness practice. Homework: } \\
\text { audio recordings for practice }\end{array}$ & 8 weeks $/ 2.5$ hours & $N / R$ & $\begin{array}{l}2^{\text {nd }} \text { and } 3^{\text {rd }} \\
\text { trimester }\end{array}$ & $\begin{array}{l}\text { Multiple } \\
\text { contacts }\end{array}$ & $\begin{array}{l}\text { Childbirth educator, prenatal } \\
\text { yoga teacher, and MBSR trainer }\end{array}$ \\
\hline $\begin{array}{l}\text { Duncan et al. } \\
\text { (2017) } \\
\text { USA }\end{array}$ & $\begin{array}{l}\text { Integrated MSBR } \\
\text { Mind in Labour } \\
\text { (MIL): Working } \\
\text { with Pain in } \\
\text { Childbirth } \\
\text { Based on MBCP }\end{array}$ & $\begin{array}{l}\text { Face to Face (group) } \\
\text { In-class: Mindfulness-Based } \\
\text { Childbirth and Parenting (MBCP) } \\
\text { and MIL components. Homework: } \\
\text { written material and audio } \\
\text { recordings for practice }\end{array}$ & 2.5 days/18 hours & $\begin{array}{l}\text { University/ } \\
\text { Academic }\end{array}$ & $\begin{array}{l}2^{\text {nd }} \text { and } 3^{\text {rd }} \\
\text { trimester }\end{array}$ & $\begin{array}{l}\text { Multiple } \\
\text { contacts }\end{array}$ & $\begin{array}{l}\text { Senior mindfulness } \\
\text { teacher and certified nurse } \\
\text { midwife (Nancy Bardacke) }\end{array}$ \\
\hline $\begin{array}{l}\text { Duncan \& } \\
\text { Bardacke (2010) } \\
\text { USA }\end{array}$ & $\begin{array}{l}\text { Mindfulness-Based } \\
\text { Childbirth and } \\
\text { Parenting } \\
\text { Adapted from } \\
\text { MBSR }\end{array}$ & $\begin{array}{l}\text { Face to face (group) } \\
\text { In-class: childbirth education and } \\
\text { mindfulness practice. Homework: } \\
\text { audio recordings for practice }\end{array}$ & $\begin{array}{l}9 \text { weeks/3 hours } \\
\text { plus 7-hour silent } \\
\text { retreat and post- } \\
\text { birth reunion }\end{array}$ & Community & $\begin{array}{l}2^{\text {nd }} \text { and } 3^{\text {rd }} \\
\text { trimester }\end{array}$ & $\begin{array}{l}\text { Multiple } \\
\text { contacts }\end{array}$ & $\begin{array}{l}\text { Author of MBCP (Nancy } \\
\text { Bardacke; registered nurse } \\
\text { midwife) }\end{array}$ \\
\hline $\begin{array}{l}\text { Dunn et al. } \\
\text { (2012) } \\
\text { Australia }\end{array}$ & $\begin{array}{l}\text { Mindful Pregnancy } \\
\text { and Childbirth } \\
\text { Generic } \\
\text { Mindfulness }\end{array}$ & $\begin{array}{l}\text { Face to face (group) } \\
\text { In-class: MBCT with adaptations. } \\
\text { Homework: audio recordings for } \\
\text { practice }\end{array}$ & 8 weeks/hours N/R & $N / R$ & $\begin{array}{l}2^{\text {nd }} \text { and } 3^{\text {rd }} \\
\text { trimester }\end{array}$ & $\begin{array}{l}\text { Multiple } \\
\text { contacts }\end{array}$ & Psychiatrist and counsellor \\
\hline
\end{tabular}




\section{International Health Trends and Perspectives}

\begin{tabular}{|c|c|c|c|c|c|c|c|}
\hline Study & Program & Format (components and design) & Weeks/Hours & $\begin{array}{l}\text { Setting } \\
\text { (sessions } \\
\text { conducted) }\end{array}$ & $\begin{array}{l}\text { Timing of } \\
\text { Perinatal } \\
\text { Intervention } \\
\text { (Gestation) }\end{array}$ & $\begin{array}{l}\text { Number of } \\
\text { contacts }\end{array}$ & Provider \\
\hline $\begin{array}{l}\text { Goodman et al. } \\
(2014) \\
\text { USA }\end{array}$ & $\begin{array}{l}\text { Coping with } \\
\text { Anxiety through } \\
\text { Living Mindfully } \\
\text { (CALM) } \\
\text { Generic } \\
\text { Mindfulness }\end{array}$ & $\begin{array}{l}\text { Face to face (group) } \\
\text { In-class: mental health education } \\
\text { and mindfulness practice. } \\
\text { Homework: audio recordings for } \\
\text { practice }\end{array}$ & 8 weeks/2hours & $\begin{array}{l}\text { University/ } \\
\text { Academic }\end{array}$ & All 3 trimesters & $\begin{array}{l}\text { Multiple } \\
\text { Contacts }\end{array}$ & $\begin{array}{l}\text { Clinical social worker trained in } \\
\text { MSBR and MBCT- supervised by } \\
\text { advanced practice nurse trained } \\
\text { in MSBR and MBCT }\end{array}$ \\
\hline $\begin{array}{l}\text { Guardino et al. } \\
(2014) \\
\text { USA }\end{array}$ & $\begin{array}{l}\text { Mindful Awareness } \\
\text { Practices (MAPS) } \\
\text { Generic } \\
\text { Mindfulness }\end{array}$ & $\begin{array}{l}\text { Face to face (group) } \\
\text { In-class: mindfulness education and } \\
\text { practice. Homework: audio } \\
\text { recordings for practice }\end{array}$ & 6 weeks/2hours & $\begin{array}{l}\text { University/ } \\
\text { Academic }\end{array}$ & $\begin{array}{l}1^{\text {st }} \text { and } 2^{\text {nd }} \\
\text { trimester }\end{array}$ & $\begin{array}{l}\text { Multiple } \\
\text { contacts }\end{array}$ & Trained MAP instructors \\
\hline $\begin{array}{l}\text { Krusche et al. } \\
\text { (2018) } \\
\text { United Kingdom }\end{array}$ & $\begin{array}{l}\text { Be Mindful Online* } \\
\text { Generic } \\
\text { Mindfulness }\end{array}$ & $\begin{array}{l}\text { Online: video, written material; } \\
\text { mindfulness practice. Homework: } \\
\text { written submission of practice }\end{array}$ & 4 weeks/hours N/R & $\begin{array}{l}\text { At home } \\
\text { (online) }\end{array}$ & All 3 trimesters & $\begin{array}{l}\text { Multiple } \\
\text { contacts }\end{array}$ & $\begin{array}{l}\text { Online using a secure site to } \\
\text { collect the data }\end{array}$ \\
\hline $\begin{array}{l}\text { Matvienko-Sikar } \\
\text { \& Dockray } \\
\text { (2017) }\end{array}$ & $\begin{array}{l}\text { Positive } \\
\text { psychological } \\
\text { intervention }\end{array}$ & $\begin{array}{l}\text { Online: written and audio } \\
\text { components. Homework: N/R }\end{array}$ & $\begin{array}{l}4 \text { times/week for } 3 \\
\text { weeks/hours N/R }\end{array}$ & $\begin{array}{l}\text { At home } \\
\text { (online) }\end{array}$ & $\begin{array}{l}1^{\text {st }} \text { and } 2^{\text {nd }} \\
\text { trimester }\end{array}$ & $\begin{array}{l}\text { Multiple } \\
\text { contacts }\end{array}$ & $\begin{array}{l}\text { Online } \\
\text { Researcher produced audio for } \\
\text { body scan practice }\end{array}$ \\
\hline
\end{tabular}


International Health Trends and Perspectives

\begin{tabular}{|c|c|c|c|c|c|c|c|}
\hline Study & Program & Format (components and design) & Weeks/Hours & $\begin{array}{l}\text { Setting } \\
\text { (sessions } \\
\text { conducted) }\end{array}$ & $\begin{array}{l}\text { Timing of } \\
\text { Perinatal } \\
\text { Intervention } \\
\text { (Gestation) }\end{array}$ & $\begin{array}{l}\text { Number of } \\
\text { contacts }\end{array}$ & Provider \\
\hline $\begin{array}{l}\text { Muthukrishnan } \\
\text { et al. (2016) }\end{array}$ & $\begin{array}{l}\text { Mindfulness } \\
\text { meditation } \\
\text { programme }\end{array}$ & $\begin{array}{l}\text { Face to face (group) } \\
\text { In-class: mindfulness practice. } \\
\text { Homework: practice }\end{array}$ & $\begin{array}{l}2 \text { sessions per week } \\
\text { for } 5 \text { weeks }\end{array}$ & $N / R$ & $\begin{array}{l}1^{\text {st }} \text { and } 2^{\text {nd }} \\
\text { trimester }\end{array}$ & $\begin{array}{l}\text { Multiple } \\
\text { contacts }\end{array}$ & $\begin{array}{l}\text { Trained university Psychology } \\
\text { Department staff }\end{array}$ \\
\hline \multicolumn{8}{|l|}{ India } \\
\hline $\begin{array}{l}\text { Pan et al. (2019) } \\
\text { Taiwan }\end{array}$ & $\begin{array}{l}\text { Mindfulness-Based } \\
\text { Childbirth and } \\
\text { Parenting } \\
\text { Based on MSBR }\end{array}$ & $\begin{array}{l}\text { Face-to-Face (group) } \\
\text { In-class: childbirth education and } \\
\text { mindfulness practice. Homework: } \\
\text { audio recordings for practice }\end{array}$ & $\begin{array}{l}6 \text { weeks/3 hours } \\
\text { session } \\
\text { plus 7-hour silent } \\
\text { retreat }\end{array}$ & Hospital & $\begin{array}{l}2^{\text {nd }} \text { and } 3^{\text {rd }} \\
\text { trimester }\end{array}$ & $\begin{array}{l}\text { Multiple } \\
\text { contacts }\end{array}$ & $\begin{array}{l}\text { Wan-Lin Pan (principal } \\
\text { investigator) trained in childbirth } \\
\text { education; Jon Kabat-Zinn } \\
\text { (designed MSBR); Nancy } \\
\text { Bardacke (designed MBCP) }\end{array}$ \\
\hline $\begin{array}{l}\text { Townshend et } \\
\text { al. (2018) } \\
\text { Australia }\end{array}$ & $\begin{array}{l}\text { Caring for Body } \\
\text { and Mind in } \\
\text { Pregnancy (CBMP) } \\
\text { Based on MBCT }\end{array}$ & $\begin{array}{l}\text { Face to face (group) } \\
\text { In-class: childbirth education and } \\
\text { mindfulness practice. Homework: } \\
\text { practice }\end{array}$ & 8 weeks/hours N/R & Hospital & All 3 trimesters & $\begin{array}{l}\text { Multiple } \\
\text { contacts }\end{array}$ & $\begin{array}{l}\text { Three facilitators, one a mental } \\
\text { health clinician }\end{array}$ \\
\hline $\begin{array}{l}\text { Vieten \& Astin } \\
(2008) \\
\text { USA }\end{array}$ & $\begin{array}{l}\text { Mindful } \\
\text { Motherhood }\end{array}$ & $\begin{array}{l}\text { Face to face (group) } \\
\text { In-class: mindfulness education and } \\
\text { practice. Homework: readings and } \\
\text { audio recordings for practice }\end{array}$ & 8 weeks $/ 2$ hours & Hospital & All 3 trimesters & $\begin{array}{l}\text { Multiple } \\
\text { contacts }\end{array}$ & $\begin{array}{l}\text { Clinical psychologist trained in } \\
\text { mindfulness and certified } \\
\text { prenatal yoga instructor }\end{array}$ \\
\hline $\begin{array}{l}\text { Warriner et al. } \\
(2018)\end{array}$ & $\begin{array}{l}\text { Mind in Labour } \\
\text { (MIL): Working } \\
\text { with Pain in }\end{array}$ & $\begin{array}{l}\text { Face to Face (group) } \\
\text { In-class: childbirth education and } \\
\text { mindfulness practice }\end{array}$ & 4 weeks $/ 2.5$ hours & Community & $\begin{array}{l}2^{\text {nd }} \text { and } 3^{\text {rd }} \\
\text { trimesters }\end{array}$ & $\begin{array}{l}\text { Multiple } \\
\text { contacts }\end{array}$ & MBCP trained midwives teams \\
\hline United Kingdom & $\begin{array}{l}\text { Childbirth } \\
\text { Based on MBCP }\end{array}$ & Homework: practice & & & & & \\
\hline
\end{tabular}


International Health Trends and Perspectives

\begin{tabular}{|c|c|c|c|c|c|c|c|}
\hline Study & Program & Format (components and design) & Weeks/Hours & $\begin{array}{l}\text { Setting } \\
\text { (sessions } \\
\text { conducted) }\end{array}$ & $\begin{array}{l}\text { Timing of } \\
\text { Perinatal } \\
\text { Intervention } \\
\text { (Gestation) }\end{array}$ & $\begin{array}{l}\text { Number of } \\
\text { contacts }\end{array}$ & Provider \\
\hline $\begin{array}{l}\text { Woolhouse et } \\
\text { al. (2014) - Part } \\
1 \text { and } 2\end{array}$ & MindBabyBody & $\begin{array}{l}\text { Face to face (group) } \\
\text { In-class: mindfulness practice. } \\
\text { Homework: audio recordings for } \\
\text { practice }\end{array}$ & 6 weeks/2 hours & Hospital & All 3 trimesters & $\begin{array}{l}\text { Multiple } \\
\text { contacts }\end{array}$ & $\begin{array}{l}\text { Psychiatrist/psychologist } \\
\text { experienced in mindfulness group } \\
\text { training }\end{array}$ \\
\hline
\end{tabular}

$\mathrm{MBI}=$ Mindfulness-based intervention; $\mathrm{MBCT}=$ Mindfulness-Based Cognitive Therapy; N/R = Not reported; $\mathrm{MBCP}=\mathrm{Mindfulness-Based} \mathrm{Childbirth}$ and Parenting; MBSR = Mindfulness-Based Stress Reduction 
Table 6. Comparison of suggested practices for adolescent education program development and perinatal mindfulness components and design features

Design features Components

Facilitator Capacity

Delivery Method

Interactive and Engaging

Curriculum

Session Length

Reflection/Discussion

Support Training

(Parent/Caregiver or Partner of Adolescent)
Suggested Practices for Adolescents
Effectiveness Perinatal Mindfulness Intervention Components and Suggestions for Adaptation
Facilitator skill set and knowledge based in the developmental learning needs of adolescents (Cheang et al., 2019; McKeering \& Hwang, 2019)

Web-based applications are feasible, acceptable, and accessible for adolescents (Logsdon et al., 2013; RNAO, 2010; Statistics Canada, 2017; Stinson, Willson, Gill, Yamada, \& Holt., 2009)

Adapt to the specific challenges of the teens (Kostova et al., 2019)

Participatory and interactive; include role play and experiential learning (Kostova et al., 2019)

Accommodate short attention spans - no longer than 90 minutes (Kostova et al., 2019)

Discussing participant goals before the session; this may improve engagement and motivation (Kostova et al., 2019)

Parent/caregiver and/or partner training in addition to adolescent training may be effective (Kostova et al., 2019)
Broad training scope of facilitators (predominantly health care providers, experts in their population, not solely in mindfulness)

Online mindfulness interventions currently exist and would require developmentally age-appropriate modifications (Krusche et al., 2018; Matvienko-Sikar \& Dockray, 2017)

Mindfulness interventions included studies which adapted interventions for perinatal populations

A variety of practices were included in the interventions: mindful movements, senses awareness and mindfulness meditation practice

Varied in length; interventions as short as five minutes were effective and design could include gradual increase over time, as tolerated

Group discussion and writing/journaling

Partner training was included in 2 studies and could be adjusted to address parent-child dynamic (Byrne et al., 2013; Duncan \& Bardacke, 2010; Warriner et al., 2018) 